\title{
Impact of mycorrhizae and irrigation in the survival of seedlings of Pinus radiata D. Don subject to drought
}

\section{Impacto de la inoculación con micorrizas y el riego en la sobrevivencia de plántulas de Pinus radiata D. Don sometidas a sequía}

\author{
Cristian Atala ${ }^{1 *}$, Edgardo Muñoz-Capponi¹ ${ }^{1}$, Gulllermo Pereira², Eduardo Navarrete ${ }^{3}$, Rómulo \\ Oses $^{4}$ \& Marco Molina-Montenegro ${ }^{5}$
}

${ }^{1}$ Laboratorio de Anatomía y Ecología Funcional de Plantas. Departamento de Ciencias y Tecnología Vegetal. Universidad de Concepción, Campus Los Ángeles, Juan Antonio Coloma 0201, Los Ángeles, Chile.

'Laboratorio de Biotecnología de Hongos. Departamento de Ciencias y Tecnología Vegetal. Universidad de Concepción, Campus Los Ángeles, Juan Antonio Coloma 0201, Los Ángeles, Chile.

${ }^{3}$ GESE. Departamento de Ciencias y Tecnología Vegetal. Universidad de Concepción, Campus Los Ángeles, Juan Antonio Coloma 0201, Los Ángeles, Chile.

${ }^{4}$ Instituto de Investigaciones Agropecuarias (INIA), Centro Regional Intihuasi, La Serena, Chile.

${ }^{5}$ Centro de Estudios Avanzados en Zonas Áridas (CEAZA), Facultad de Ciencias del Mar, Universidad Católica del Norte, Coquimbo, Chile.

*catala@udec.cl

\begin{abstract}
In drought condition, plants increase survival chance by adjusting their functional traits and by biological associations. Mycorrhizae association and artificial watering have been shown to increase plant survival under drought, especially at early developmental stages when plants are more susceptible. In Chile, Pinus radiata is the most important forest species. It is grown mainly in Central Chile, where precipitations are predicted to drop in $40 \%$ and change in frequency in the future due to climate change. Rhizopogon luteolus is an ectomycorrhizae usually associated with Pinus species and has been found to increase drought tolerance. We addressed the effect of $R$. luteolus inoculation on survival and functional traits of $P$. radiata seedlings exposed to two watering treatments. These treatments simulated control (50 ml) and $40 \%$ reduced precipitations $(20 \mathrm{ml})$. We also evaluated the combined effect of watering quantity $(20$ and $50 \mathrm{ml})$ and frequency (every 5 , 10 and 30 days) on the same variables. R. luteolus inoculation increased seedling survival, but reduced plant size. Watering quantity affected plant survival only at intermediate watering frequencies, but not at the high and low frequencies. The lowest frequency, normal for the summer of Central Chile, resulted in $\sim 80 \%$ seedling mortality. Most of the functional traits measured were not affected neither by watering frequency nor quantity, but they were affected by mycorrhization. Mycorrhizae inoculation, together with some sort of artificial watering could be a possible strategy to cope with prolonged drought events.
\end{abstract}

KeYwords: Pinus radiata, Rhizopogon luteolus, climate change, ectomycorrhizae, drought tolerance.

\section{RESUMEN}

En condiciones de sequía, las plantas aumentan la probabilidad de sobrevivir ajustando sus rasgos funcionales y por medio de asociaciones biológicas. Las asociaciones micorrícicas y el riego artificial aumentan la sobrevivencia en condiciones de sequía, especialmente en etapas tempranas del desarrollo, cuando las plantas son más sensibles. En Chile, Pinus radiata es la especie forestal más importante. Se planta principalmente en Chile central, donde se predice que las precipitaciones disminuirán en un $40 \%$ y cambiará su frecuencia en el futuro debido al cambio climático. Rhizopogon luteolus es una ectomicorriza usualmente asociada a especies de Pinus y se ha encontrado que aumenta la tolerancia a la sequía. Se analizó el efecto de la inoculación de $R$. luteolus en la sobrevivencia y rasgos funcionales de plántulas de $P$. radiata expuestas a dos tratamientos de riego. Estos tratamientos simulan precipitaciones control $(50 \mathrm{ml})$ y reducidas a un $40 \%$ (20 ml). También se evaluó el efecto combinado de la cantidad $(20$ y $50 \mathrm{ml}$ ) y frecuencia (cada 5, 10 y 30 días) de riego en las mismas variables. La inoculación con $R$. luteolus aumentó la sobrevivencia pero redujo el tamaño de las plántulas. La cantidad de riego afectó la sobrevivencia de las plantas sólo en la frecuencia intermedia de riego, pero no en las frecuencias alta y baja. La frecuencia más baja, normal para el verano de Chile central, resultó en $\sim 80 \%$ de mortalidad de plántulas. La mayoría de los rasgos funcionales no fueron afectados por la frecuencia o cantidad de riego, pero si por la micorrización. La inoculación 
Impact of mycorrhizae and irrigation on Pinus radiata: Atala, C. ET AL.

con micorrizas, en conjunto con algún tipo de riego artificial, podría ser una posible estrategia para lidiar con eventos de sequía prolongada.

Palabras clave: Pinus radiata, Rhizopogon luteolus, cambio climático, ectomicorrizas, tolerancia a la sequía.

\section{INTRODUCTION}

Water is one of the most important factors in plant productivity across ecosystems. Water availability affects plant survival and impact several morphological and physiological traits (Atala \& Gianoli 2009, Grace 1997, Molina-Montenegro et al. 2011, Pedrol et al. 2000). Water limitation usually results in reduced water loss and increased water use efficiency. Plants exposed to drought show reduced leaf area, higher root/shoot ratio, and smaller tracheid radius (Atala \& Gianoli 2009, Gianoli \& GonzálezTeuber 2005, Hunt \& Nicholls 1986, Molina-Montenegro et al. 2011). Additionally, low water potential rapidly induces stomatal closure, reducing stomatal conductance (Schulze 1986), and hence limiting photosynthesis. Overall, growth is reduced in water-limited plants, mainly due to reduced carbon gain.

It has been shown that plant species have developed morpho-physiological mechanisms to cope with stressful environments (Molina-Montenegro et al. 2011). Plants have also developed association with microorganisms as another successful strategy to cope with environmental stress. Ectomycorrhizae are a type of mycorrhizal fungi in which the mycelium is located in the outer layer of the roots, and are commonly found associated with forest species (Gurevitch et al. 2006). This type of fungi has been shown to provide drought tolerance to some vascular plants (HarrisValle et al. 2009, Ortega et al. 2004, Steinfield et al. 2003), particularly in early ontogenetical stages (Lamhamedi et al. 1990, 1992, Ortega et al. 2004). Rhizopogon luteolus is an ectomycorrhizic fungus that grows associated with pine species, particularly in the sandy soils of Bío-Bío district in Chile (Pereira et al. 2007, 2010a). R. luteolus has been shown to improve plant performance and establishment under water stress (Castellano 1996, Steinfeld et al. 2003, Theodorou 1971, Theodorou \& Bowen 1970).

Precipitations are projected to decline in the future in some areas due to climate change (IPCC 2007). The precipitations in Central Chile have declined in the last 50 years and some models predict that they will be further reduced in the future reaching a decrease of $40-50 \%$ (IPCC 2007). Climatic change could result in salinization and desertification of the soils in Central Chile, reducing the possibilities for agriculture and forestry.

Watering is a common and expensive practice for many crops, and helps maintain an adequate moisture level and assures continuous growth (Johnson 1986). The amount and frequency of watering depends on age, time of the year, and climatic conditions (Starkey 2002). Still it is not clear whether the frequency or the amount of watering is the most relevant factor for plant survival, but probably the relative importance of frequency and quantity depends on the species, and developmental stage.

Individuals of Pinus radiata D. Don are used for the forestry industry worldwide, mainly due its growth rate and wood quality. In Chile, Pinus radiata is the most important commercial timber species. In 2003, Chile had 1.4 million ha planted with this species (INFOR 2009), and 61,560 ha were established in 2005 (INFOR 2009). By 2008 Pinus radiata plantations corresponded to $63.32 \%$ of the total area of planted and managed forest species (INFOR 2009). In a future scenario of global change, with reduced precipitation, some regions in Chile will not be fit to support Pinus radiata growth and survival. This could negatively impact the forestry industry, an important source of income for the country.

The present study addresses the effect of water frequency and quantity in seedlings of Pinus radiata with and without Rhizopogon luteolus inoculation. We evaluated plant survival, growth, and some morphological, anatomical and allocation traits. Specifically, we addressed the following hypothesis: $i$ ) if inoculation with $R$. luteolus can increase survival in $P$. radiata seedling when exposed to drought and $i$ i) if watering quantity or watering frequency is more relevant for plant survival and growth.

\section{MATERIALS AND METHODS}

\section{Seedling establishment}

Pinus radiata plants were grown in polyethylene trays with $260 \mathrm{ml}$ sockets, filled with soil made from composted pine bark. We used separated trays for uninoculated plants (C) and for plants inoculated with Rhizopogon luteolus (I). Separated trays prevented contamination of control plants. Trays were put in a greenhouse and moved weekly to avoid blocking effect. We planted 3-4 pine seeds per socket, and after establishment, only one seedling were left in each socket. Plants were watered to field capacity $(50 \mathrm{ml})$ with tap water every day until the initiation of the treatments (see below). One uninoculated tray was used for the mycorhizae experiment as a control, and another one was used for the watering frequencies experiment.

SPORE SUSPENSION AND INOCULATION

We prepared a suspension containing Rhizopogon luteolus 
spores in a glass bottle. The bottle was cover in foil in order to maintain a dark environment. The suspension was put in a shaker at $80 \mathrm{rpm}$ and maintained in constant agitation at $24^{\circ} \mathrm{C}$ for $24 \mathrm{~h}$. This ensured the hydration of the spores that were obtained from dry carpophore samples. After 24 $\mathrm{h}$ the solution was kept at $4^{\circ} \mathrm{C}$. To check for effective spore concentration, the spore suspension was filtered and $1 \mathrm{~mL}$ of hydrated spores was diluted in $10 \mathrm{ml}$ of distilled water. A sample of this diluted solution was put in a cover and observed under the microscope. Spores were counted and a final concentration of $5.4 \times 10^{8}$ spores $/ \mathrm{ml}$ was obtained. We applied $1 \mathrm{ml}$ of the spore suspension to Pinus radiata plants obtaining inoculated individuals (I). The inoculation was repeated three times to ensure mycorrhizal association.

\section{WATERING TREATMENTS}

We measured the percentage of field capacity with a soil moisture tester (Kel Instruments Co., Inc., Japan) and established that $50 \mathrm{ml}$ were sufficient to reach field capacity. Plants with and without mycorrhizae were randomly assigned to 2 watering treatments ( $n=28$ plant per treatment). Control plants were watered every 10 days with $50 \mathrm{ml}$ of tap water. Plants exposed to drought were watered every $10 \mathrm{~d}$ with $40 \%$ the water necessary to reach field capacity (i. e. 20 $\mathrm{ml}$ ). Separately, 30 plants were randomly assigned to three watering frequencies (every 5,10 or 30 days, $n=10$ plant per treatment). The full watering experiment lasted 60 days (two 30 days cycles).

Before the beginning of the experiment, one plant per treatment was sacrificed to check microscopically for mycorrhizae presence. At the beginning of the watering treatments all plants were 1 year old and of similar size (ANOVA, $\mathrm{p}<0.05$, data not shown) and condition.

The experiment was conducted in a greenhouse at Universidad de Concepción, Campus Los Ángeles, Chile in spring-summer 2010. The greenhouse did not have any temperature or moisture levels controlling mechanism.

\section{MEASURED TRAits}

We measured plant height and crown width every 10 days from the beginning of the experiment up to 60 days. We also measured percentage of field capacity to 10 randomly selected sockets twice to check for the effects of the watering treatments in the soil. Plant survival was registered daily. Relative growth rate (RGR) was calculated as $\mathrm{RGR}=[$ final height - initial height]/initial height.

After 60 days from the beginning of the watering treatments, the experiment was concluded and all plants were collected for biomass measurements. Plants were separated in roots, leaves, and stem. We counted leaves per plant, and cut a transversal section of the stem close to the crown. The transversal section was photographed using a microscope (Primo Star, Carl Zeiss, Germany) connected to a digital camera (Cannon EOS), and digital images were obtained. Using image software (Axiovision 4.6, Carl Zeiss MicroImaging GmbH, Jena, Germany) we measured tracheid lumen area. All plant portions were then put in an oven at 75 ${ }^{\circ} \mathrm{C}$ for $72 \mathrm{~h}$. Dry weight of roots and shoot (stem + leaves) was obtained using an analytical scale. We registered plant height and stem width every 2 weeks for 60 days.

\section{STATISTICAL ANALYSIS}

The effects of water quantity and water frequency on growth and biomass allocation traits were compared using two-way ANOVA's. For all two-way ANOVA's, the assumptions of normality and homogeneity of variances were tested using the Shapiro-Wilks and Bartlett tests, respectively (Zar 1999). To compare the survival curves of $P$. radiata seedlings with and without mycorrhizae inoculation and with different quantity and frequency of water were estimated by means of the Kaplan-Meier method, and statistical differences were assessed with the Cox-Mantel test (Fox 1993).

\section{RESULTS}

\section{MYCORRHIZA INOCULATION}

No mortality was recorded before the beginning of the watering treatments. After the initiation of the watering treatments, many individuals died, especially in the drought treatment, and without mycorrhizae (Fig. 1). At the end of the experiment, survival for inoculated plants watered with $50 \mathrm{ml}$ was around $60 \%$ and close to $50 \%$ for control plants (Fig. 1). While half of the inoculated plants watered with 20 $\mathrm{ml}$ survived after 60 days, only a quarter of the uninoculated plants under the same watering survived (Fig. 1). Overall, mycorrhizae infection significantly increased plant survival in both watering treatments (Cox-Mantel test, $\mathrm{p}=0.012$, Fig. 1).

Mycorrhization affected all measured plant traits (Table I, two-way ANOVA, $\mathrm{p}<0.05$ ) except RGR (Table I, twoway ANOVA, $p>0.05)$. Watering affected only RGR (Table I, two-way ANOVA, $\mathrm{p}<0.05$ ). The only significant interactions found between $R$. luteolus inoculation and watering were for RGR and root/shoot ratio (Table I, twoway ANOVA, p < 0.05). Mycorrhization decreased plant size and weight in both watering treatments and increased the root/shoot ratio, but only in the $50 \mathrm{ml}$ treatment (Table II, Tukey test, $\mathrm{p}<0.05$ ). Inoculation also decreased stem width and RGR but only in plants watered with $50 \mathrm{ml}$ (Table II, Tukey test, $\mathrm{p}<0.05$ ). Plants watered with $50 \mathrm{ml}$ had wider stems and higher RGR compared to plants watered with 20 $\mathrm{ml}$, but only in the control (uninoculated) treatment (Table II, Tukey test, $\mathrm{p}<0.05$ ).

WATERING FREQUENCIES

After 30 days of the initiation of the watering treatments the first plants begun to die (Fig. 2). Plants watered every 5 days 
had almost no mortality in both watering quantities (CoxMantel test, $p=0.012$, Fig. 2). Plants watered every 10 days with $50 \mathrm{ml}$ survived significantly more than plants watered every 10 days with $20 \mathrm{ml}$ and less than plants watered every 5 days (Cox-Mantel test, $\mathrm{p}=0.012$, Fig. 2). Plants watered every 30 days with 20 or $50 \mathrm{ml}$ had the higher mortality, similar to plants watered every 10 days with $20 \mathrm{ml}$ (CoxMantel test, $\mathrm{p}=0.012$, Fig. 1).

Watering frequency significantly affected leaves number, and watering quantity affected stem width (Table III, two-way ANOVA, $p<0.05$ ). The only significant

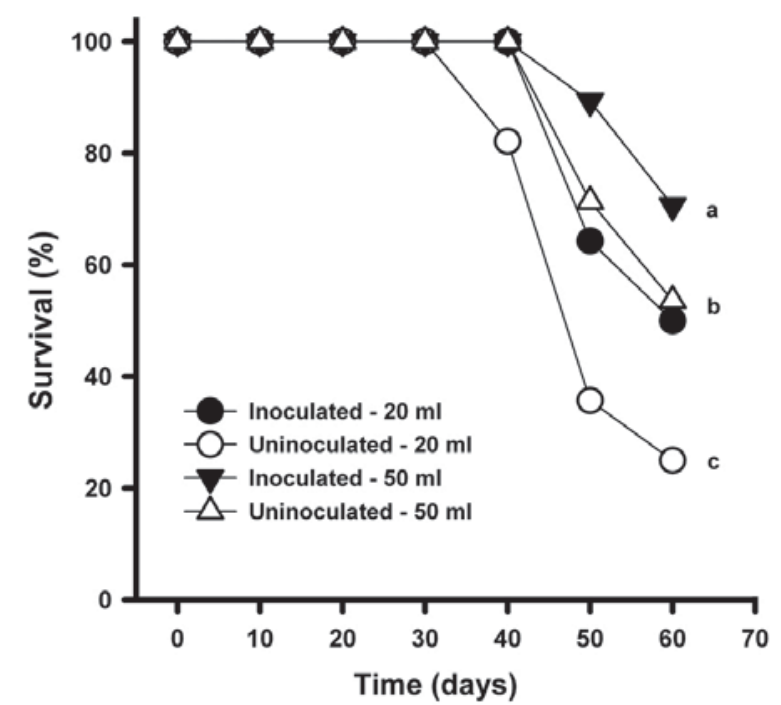

FIgURE 1. Survival of Pinus radiata seedling inoculated and notinoculated with Rhizopogon luteolus under two watering treatments. Different letters show statistically significant differences (CoxMantel test, $\mathrm{p}=0.012) . n=28$ plants per treatment.

Figura 1. Sobrevivencia de plántulas de Pinus radiata inoculadas y no inoculadas con Rhizopogon luteolus bajo dos regímenes de riego. Letras diferentes muestran diferencias significativas (CoxMantel test, $\mathrm{p}=0.012) . n=28$ plantas por tratamiento. interaction found between watering frequency and quantity was for stem width (Table III, two-way ANOVA, $\mathrm{p}<0.05$ ). Marginally significant effects were found for the effect of watering frequency on plant height and RGR, and for the effect of the interaction between frequency and quantity on root/shoot ratio (Table III). Plants watered every 5 days with $50 \mathrm{ml}$ had thicker stems compared to plants watered with $20 \mathrm{ml}$ every 5 and 30 days (Table IV, Tukey test, $\mathrm{p}<0.05$ ). Plants watered every 5 days and with 20 and $50 \mathrm{ml} \mathrm{had} \mathrm{more}$ leaves compared to plants watered every 30 days with $20 \mathrm{ml}$ (Table IV, Tukey test, $\mathrm{p}<0.05$ ).

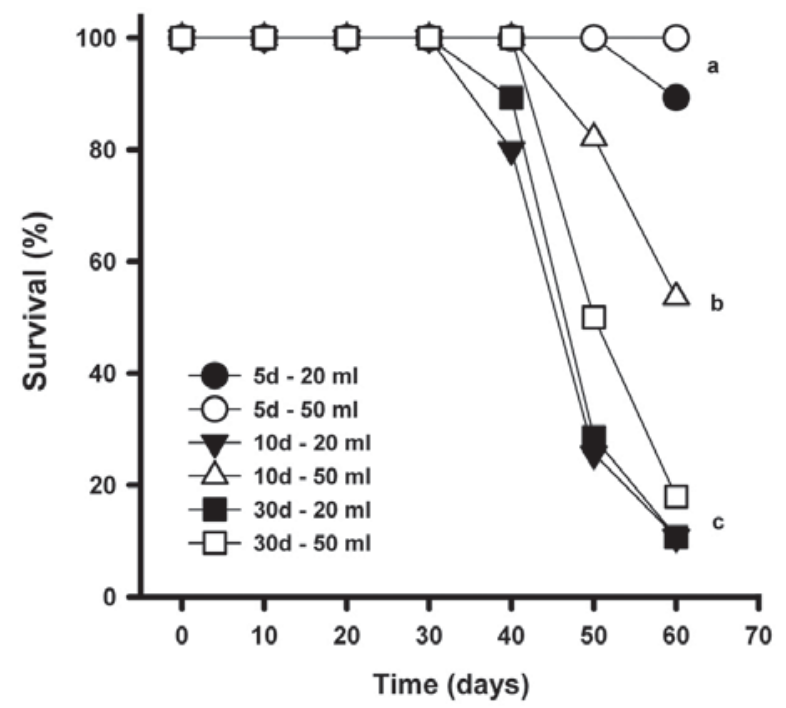

FIgURE 2. Survival of Pinus radiata seedling exposed to a combination of three watering frequencies and two watering quantities. Different letters show statistically significant differences (Cox-Mantel test, $\mathrm{p}=0.009$ ). $n=10$ plants per treatment.

Figura 2. Sobrevivencia de plántulas de Pinus radiata expuestas a una combinación de tres frecuencias de riego y dos cantidades de riego. Letras diferentes muestran diferencias significativas (CoxMantel test, $\mathrm{p}=0.009) . n=10$ plantas por tratamiento.

TABLE I. $p$-values from the two-way ANOVA testing the effect of Rhizopogon luteolus inoculation and watering quantity on Pinus radiata functional traits. $n=28$ plants per treatment.

TABLA I. Valores de p del ANOVA de dos vías testeando el efecto de la inoculación con Rhizopogon luteolus y la cantidad de riego en rasgos funcionales de Pinus radiata. $n=28$ plantas por tratamiento.

\begin{tabular}{|c|c|c|c|c|c|c|c|c|}
\hline & $\begin{array}{l}\text { FINAL STEM } \\
\text { WIDTH }(\mathrm{mm})\end{array}$ & $\begin{array}{l}\text { FINAL HEIGHT } \\
(\mathrm{cm})\end{array}$ & $\begin{array}{c}\text { RGR } \\
\left(\mathrm{cm} \mathrm{day}^{-1}\right)\end{array}$ & $\begin{array}{c}\text { NuMBER OF } \\
\text { LEAVES }\end{array}$ & $\begin{array}{c}\text { LEAVES } \\
\text { WEIGHT }(\mathrm{g})\end{array}$ & $\begin{array}{l}\text { ROOT WEIGHT } \\
\text { (g) }\end{array}$ & $\begin{array}{c}\text { STEM } \\
\text { WEIGHT }(\mathrm{g})\end{array}$ & $\begin{array}{l}\text { RoOT/ } \\
\text { SHOOT }\end{array}$ \\
\hline INOCULATION & $<0.0001$ & $<0.0001$ & 0.1063 & $<0.0001$ & $<0.0001$ & $<0.0001$ & $<0.0001$ & 0.0150 \\
\hline WATERING & 0.5900 & 0.6472 & 0.0220 & 0.6585 & 0.6629 & 0.6491 & 0.9511 & 0.2701 \\
\hline $\begin{array}{l}\text { INOCULATION X } \\
\text { WATERING }\end{array}$ & $<0.0001$ & 0.2102 & 0.9187 & 0.3848 & 0.3200 & 0.7817 & 0.0902 & 0.0057 \\
\hline
\end{tabular}




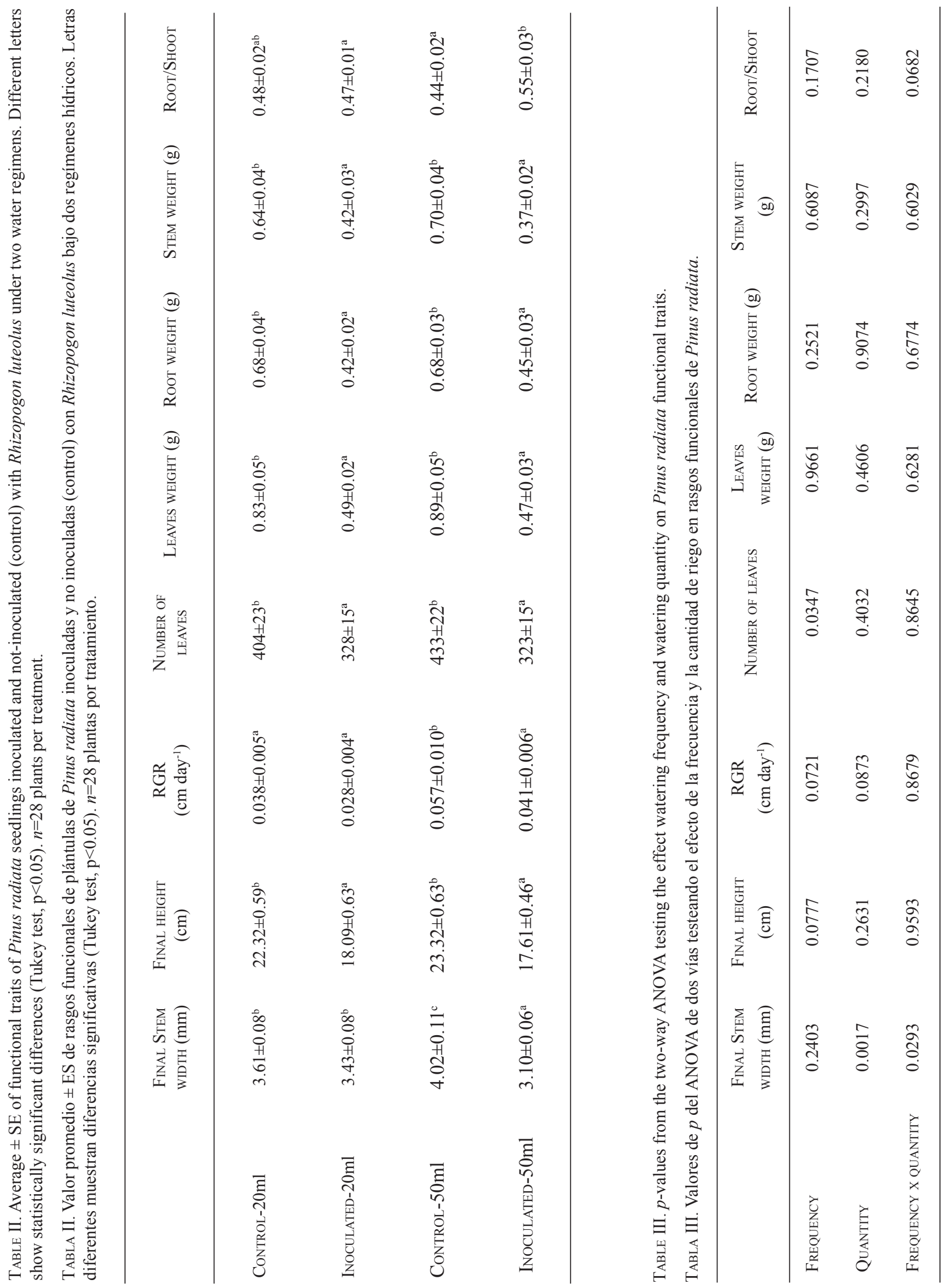


Impact of mycorrhizae and irrigation on Pinus radiata: Atala, C. ET AL.

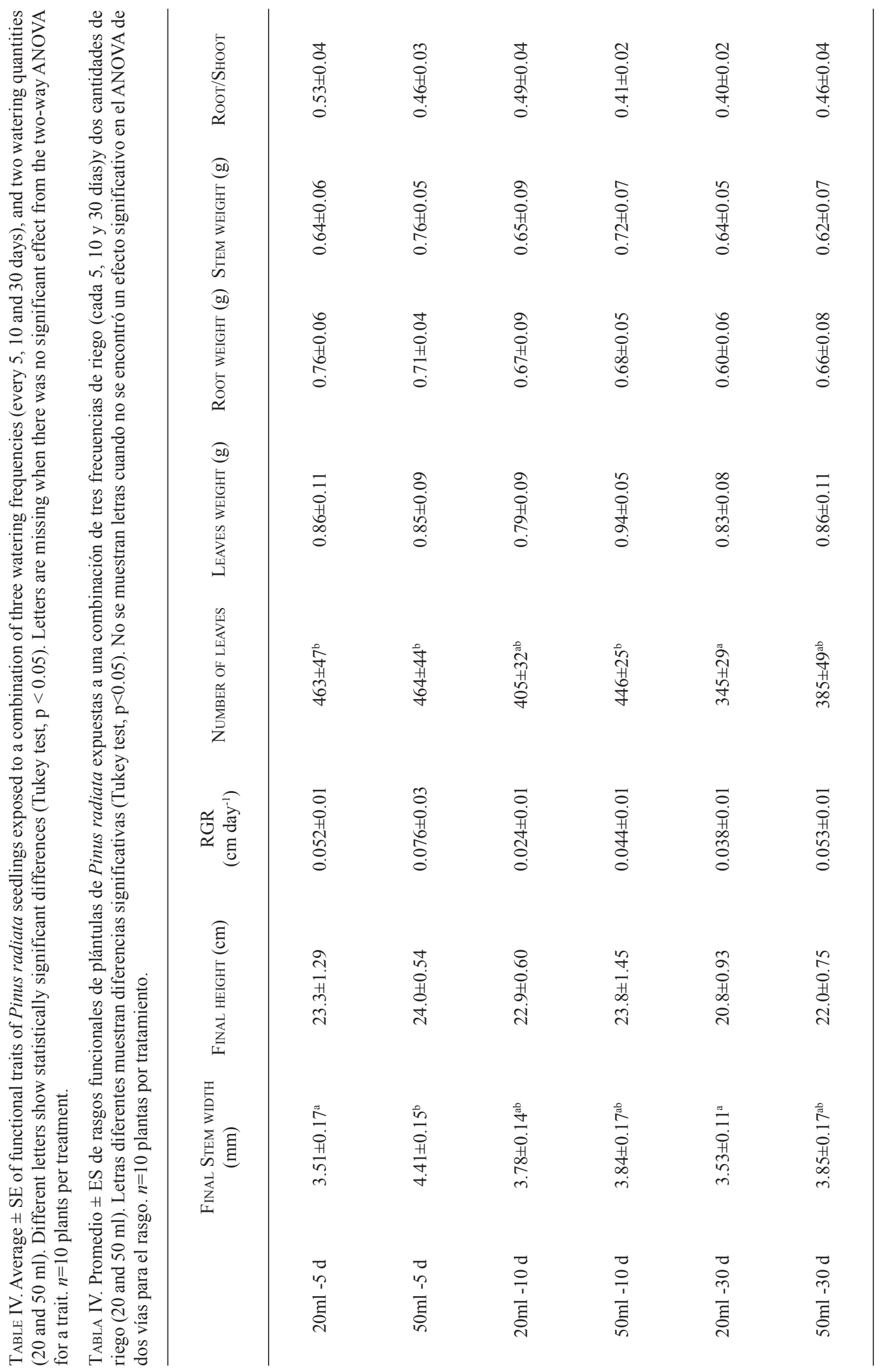




\section{DISCUSSION}

The survival of Pinus radiata seedling exposed to drought was increased by previous inoculation with $R$. luteolus. This increased drought tolerance due to mycorrhizae inoculation has been previously reported for different plant species (Ortega et al. 2004, Steinfeld et al. 2003). It has been shown that mycorrhizae can induce root hair bifurcation, growth and survival (Brundrett et al. 1996, Duan et al. 1996). In our work, inoculated plants had higher root/shoot ratio compared to control plants. A higher root/shoot results in greater effective absorption surface and exploration of new areas in the soil (Hunt \& Nichols 1986). Mycorrhization also increased average tracheid radius. This implies greater water conductance, and hence, higher carbon gain (Hubbard et al. 2001, Meinzer \& Grantz 1990, Sperry \& Pockman 1993). Mycorrhization could ameliorate the negative effects of drought via increasing root surface and sustaining higher levels of water supply to the leaves, increasing photosynthesis. Rhizopogon inoculation has been found to increase the photosynthetic rate and stomatal conductance in Pseudotsuga menziesii seedlings (Dosskey et al. 1990). It has been suggested that higher photosynthetic rate enhance the biomass, growth and survival in conifer seedlings (Pinto et al. 2012). This way, mycorrhization can improve the performance of trees in two ways: maintaining higher gas exchange in shoot enhancing the carbon up-take, and avoiding the negative effects of water shortage in root zone through of higher absorptive capacity for water and mineral nutrients (Kipfer 2011).

Despite the positive effect on survival, mycorrhization reduced plant size (height and dry weight) and did not significantly affect RGR. This could be explained by carbon movement from the plant to the fungi. Mycorrhizae obtain their carbon mostly from their host plant (Read 1987, Harris-Valle et al. 2009), resulting in a greater carbon demand in mycorrhizated roots compared to non-infected roots (Paul et al. 1985, Harris-Valle et al. 2009). Carbon export to mycorrhizae has been found in Rhizopogon vinicolor infecting other Pinaceae species (Dosskey et al. 1990). Mycorrhizae inoculation can also cause increased transpiration (Pallardy et al. 1995), and hence, reduce the leaf water potential, increasing stomatal limitations for carbon gain.

At the highest and lowest watering frequencies (every 5 and 30 days respectively), watering quantity did not have any significant effect on plant survival. At the intermediate frequency (every 10 days), however, higher watering quantity resulted in increased survival. In a global change scenario with reduced precipitation (IPCC 2007), watering could be a possible strategy to increase Pinus radiata survival for the forestry industry; especially in early developmental stages. According to our results, a high watering frequency with relatively low watering quantity should avoid/reduce seedling mortality. The sparser watering frequencies (every 10 and 30 days) imposed severe drought stress on plant, impacting survival and growth. Previous studies on Pinus species have used less severe watering frequencies (Villar et al. 2000, Puértolas 2003), but in order to assess a more realistic scenario, the treatments used in our study represent the rain frequency usually recorded in summer for central Chile (Di Castri \& Hajek 1976). In a future scenario of global change, with reduced precipitation, as suggested for several models (IPCC 2007), some regions in Chile will not be fit to support Pinus radiata growth and survival. This could negatively impact the forestry industry, an important source of income for the country. Watering in Chilean forestry is currently an uncommon practice, used only for some intensive plantations (Reyna \& Colina 2007, Pereira et al. 2010b). If precipitations decline as predicted, watering could become a necessary managing strategy in the future.

In the forestry industry, plants are initially grown in nurseries. This helps in maintaining an adequate moisture level to avoid growth limitations (Landis et al. 1989, Lopushinsky 1990, Prieto et al.2004). Watering is commonly used in order to maintain the plant water potential above $0.5 \mathrm{MPa}$ (Landis et al. 1989, Prieto et al. 2004). Watering at the nursery improves plant quality and the likelihood of survival at later stages (Birchler et al. 1998). Mycorrhization and watering at early ontogenetical stages could be a feasible strategy to cope with plant mortality due to water stress after seedling establishment.

Several eco-physiological traits that enhance performance under drought are frequently looked for in plants to be used in reforestation of Mediterranean ecosystems (Vallejo et al. 2005). However, in stressed plants, different functional traits and management strategies are mixed, and evidence for which combinations could be advantageous in new climatic scenarios is scant and often speculative. For instance, our study suggested that high drought tolerance coupled with a conservative water use (condition observed with mycorrhizae inoculation) seems to render good results under current climatic conditions, where chronic drought alternates with seasonal rainfall. But mycorrhization as a successful strategy to enhance performance under future scenarios, characterized by extreme aridity and more unpredictable rainfall, can not be definitively concluded, and some sort of irrigation will be necessary to sustain forestry production.

\section{CONCLUSIONS}

Rhizopogon luteolus inoculation ameliorates drought stress on Pinus radiata seedling, but limits growth when water availability is higher. An increase in $60 \%$ in watering quantity is only relevant for seedling survival at intermediate watering frequencies (every 10 days). When frequencies were low (every 30 days) or high (every 5 days), the amount 
of water supplied was irrelevant for seedling survival. At the intermediate watering frequency (every 10 days), survival is similar in inoculated plants watered with $20 \mathrm{ml}$ and uninoculated plants watered with $50 \mathrm{ml}$. Thus, mycorrhizae inoculation could replace a higher watering quantity in order to maintain seedling survival, reducing the demand for irrigation water.

\section{ACKNOWLEDGEMENTS}

Kathleen Cid for technical work; UIRII and Departamento de Ciencias y Tecnología, UdeC, Campus Los Ángeles for funding.

\section{REFERENCES}

Atala, C. \& E. Gianoli. 2009. Effect of water availability on tolerance of leaf damage in tall morning glory, Ipomoea purpurea. Acta Oecologica 35: 236-242.

Birchler, T., R.W. Rose, A. Royo \& M. Pardos. 1998. La planta ideal: revisión del concepto, parámetros definitorios e implementación práctica. Investigación Agraria: Sistemas de Recursos Forestales 7: 109-116.

Brundrett, M., N. Bougher, B. Dell, T. Grove \& N. Malajczuk. 1996. Working with mycorrhizas in forestry and agriculture. ACIAR Monograph 32, ACIAR, Canberra.

Castellano, M.A.1996. Outplanting performance of mycorrhizal inoculated seedlings. In: K.G. Mukerji (ed.), Concepts in Mycorrhizal Research, pp 223-301. Kluwer Academic Publishers, Netherlands.

Di Castri, F. \& E.R. HajeK. 1976. Bioclimatología de Chile. Editorial de la Universidad Católica de Chile, Santiago, Chile. 129 pp.

Dosskey, M.G., R.G. Linderman \& L. Boersma. 1990. Carbon-sink stimulation of photosynthesis in Douglas-fir seedlings by some ectomycorrhizae. New Phytologist 115: 269-274.

Duan, X., D.S. Neuman, J.M. Reiber, C.D. Green, A.M. Saxton \& R.M. Augé. 1996. Mycorrhizal influence on hydraulic and hormonal factors involved in the control of stomatal conductance during drought. Journal of Experimental Botany 47: 1541-1550.

Fox, G.A. 1993 Failure time analysis: emergence, flowering, survivorship, and other waiting times. In: S.M. Scheiner \& J. Gurevitch (eds), Design and analysis of ecological experiments, pp 253-289. Oxford University Press, Oxford, UK.

Gianoli, E. \& M. González-Teuber. 2005. Environmental heterogeneity and population differentiation in plasticity to drought in Convolvulus chilensis (Convolvulaceae). Evolutionary Ecology 19: 603-613.

Grace, J. 1997. Plant water relations. In: M.J. Crawley (ed.), Plant Ecology, pp 28-50. Blackwell, Oxford, UK.

Gurevitch, J., S.M. Scheiner \& G.A. Fox. 2006. The ecology of plants, second ed. Sinauer, Sunderland, MA, USA. 518 pp.

Harris-Valle, C., M. Esqueda, E. Valenzuela-Soto \& A.
Castellano. 2009. Tolerancia al estrés hídrico en la interacción planta-hongo micorrízico arbuscular: metabolismo energético y fisiología. Revista Fitotécnica Mexicana 32: 265-271.

Hubbard, R.M., V. Stiller, M.G. Ryan \& J.S. Sperry. 2001. Stomatal conductance and photosynthesis vary linearly with plant hydraulic conductance in ponderosa pine. Plant, Cell \& Environment 24: 113-121.

Hunt, R. \& A.O. Nicholls. 1986. Stress and the coarse control of growth and root-shoot partitioning in herbaceous plants. Oikos 47: 149-158.

INFOR. 2009. Exportaciones Forestales Chilenas 2008. Boletín Estadístico $\mathrm{N}^{\circ} 122$. Instituto Forestal, Centro de Información Forestal. Santiago, Chile. 96 pp.

IPCC. 2007. Intergovernmental Panel on Climate Change. http:// www.ipcc.ch

JoHNSON, J.D. 1986. Irrigation and its implications for seedling growth and development. En: Proceedings of the Southern Forest Nursery Conference, pp 60-68. USDA Forest Service, Southern Region, Pensacola, FL.

Kipfer, T., B. Moser, S. Egli, T. Wohlgemuth \& J. Ghazoul. 2011. Ectomycorrhiza succession patterns in Pinus sylvestris forests after stand-replacing fire in the Central Alps. Oecologia 167: 219-228.

Lamhamedi, M.S., P.Y. Bernier \& J.A. Fortin. 1992. Hydraulic conductance and soil water potential at the soil-root interface of Pinus pinaster seedlings inoculated with different dikaryons of Pisolithus sp. Tree Physiology 10: 231-244.

Lamhamedi, M.S., J.A. Fortin, H.H. Hope \& B.R. Kropp. 1990. Genetic variation in ectomycorrhiza formation by Pisolithus arhizus on Pinus pinaster and Pinus banksiana. New Phytologist 115: 689-697.

Landis, T.D., R.W. Tinus, S.E. McDonald \& J.P. Barnett. 1989. Seedling mutrition and irrigation. Vol. 4. The container tree nursery manual. USDA, Forest Service. Agric. Handbl. $674 \mathrm{pp}$.

Lopushinsky, W. 1990. Seedling moisture status. Proceedings of the Target Seedling Symposium, Aug. 13-17, Western Forest Nursey Association, Roseburg, pp: 123-138.

Meinzer, F.C. \& D.A. Grantz. 1990. Stomatal and hydraulic conductance in growing sugarcane: Stomatal adjustment to water transport capacity. Plant, Cell \& Environment 13: 383-388.

Molina-Montenegro, M.A., C.L. Quiroz, C. Torres-Díaz \& C. Atala. 2011. Functional differences in response to drought in the invasive Taraxacum officinale from native and introduced alpine habitat ranges. Plant Ecology \& Diversity 1: 37-44.

Ortega, U., M. Duñabeitia, S. Menéndez, C. González-Murúa \& J. MAJADA. 2004. Effectiveness of mycorrhizal inoculation in the nursery on growth and water relations of Pinus radiata in different water regimes. Tree Physiology 24: 65-73.

Pallardy, S.G., J. Cermak, F.W. Ewers, M.R. Kaufmann, W.C. PARKer \& J.S. SPERRY. 1995. Water transport dynamics in trees and stands. In: W.K. Smith \& T.M. Hinckley (eds.), Resource physiology of conifers, pp. 301-389. Academic Press, New York, USA.

Paul, E.A., D. Harris \& A. Fredeen. 1985. Carbon flow in 
mycorrhizal plant associations. In: R. Molina (ed.), The Proceedings of the 6th North American Conference on Mycorrhizae, pp. 165-169. Oregon State University Forest Research Laboratory, Corvallis, OR, USA.

Pedrol, N., P. Ramos \& M.J. Reigosa. 2000. Phenotypic plasticity and acclimation to water deficits in velvet-grass: a longterm greenhouse experiment. Changes in leaf morphology, photosynthesis and stress-induced metabolites. Journal of Plant Physiology 157: 383-393.

Pereira, G., J. Herrera, A. Machuca \& M. Sánchez. 2007. Efecto del $\mathrm{pH}$ sobre el crecimiento in vitro de hongos ectomicorrícicos recolectados de plantaciones de Pinus radiata. Bosque 28: 215-219.

Pereira, G., J. Herrera, A. Machuca, D. Chávez \& M. Sánchez. 2010a. Incidencia del medio de cultivo y sitio de recolección en el crecimiento in vitro de tres especies de hongos ectomicorrícicos. En: M.A. Herrera \& R. Carociolo (eds.), Gestión forestal sostenible. Perspectivas y nuevos paradigmas frente al cambio global, pp. 275-285. Editores Universidad de Córdoba, Spain.

Pereira, G., D. Chávez, A. Machuca, L. Martínez-Suz \& M. Honrubia. 2010b. Trufas. Alternativa de cultivo para agroforestadores de la Provincia del Bío Bío. Fondo de Innovación Tecnológica de la Región del Bío Bío. Editorial Universidad de Concepción. Los Ángeles, Chile. 46 pp.

Pinto, J.R., J.D. Marshall, R.K. Dumroese, A.S. Davis \& D.R. CoBos. 2012. Photosynthetic response, carbon isotopic composition, survival, and growth of three stock types under water stress enhanced by vegetative competition. Canadian Journal of Forest Research 42: 333-344.

Prieto, J.A., E.H. Cornejo, P.A. Domínguez, J.J. NÁvar, J.G. Marmolejo \& J. JimÉnez. 2004. Estrés hídrico en Pinus engelmannii Carr., producido en vivero. Investigación Agraria: Sistemas de Recursos Forestales 13(3): 443-451.

PUÉrTOLAS, J. 2003. Efecto del riego y la fertilización nitrogenada sobre la calidad de planta de Pinus halepensis Mill. y su comportamiento en campo. Doctoral Thesis, Universidad Politécnica de Madrid, Spain. 153 pp.

READ, D.J. 1987. Development and function of mycorrhizal hyphae in soil. In: D.M. Sylvia, L.L. Hung \& J.H. Graham (eds.), The Proceedings of the 7th North American Conference on Mycorrhizae, pp. 178-180. University of Florida, Gainesville, USA.

Reyna, S. \& C. Colina. 2007. Truficultura. En: Truficultura. Fundamentos y técnicas. Reyna Domenecha (Coordinador) Ediciones Mundi-Prensa. España. pp. 237-276.

Schulze, E.D. 1986. Whole-plant responses to drought. Australian Journal of Plant Physiology 13: 127-141.

Sperry, J.S. \& W.T. Pockman. 1993. Limitation of transpiration by hydraulic conductance and xylem cavitation in Betula occidentalis. Plant, Cell \& Environment 16: 279-287.

StarkeY, T.E. 2002. Irrigation and fertilization type, rate and frequency of application. In: J.P. Barnett, R.K. Dumroese \& D.J. Moorhead (eds.), Proceedings of Workshops on Growing Longleaf Pine in Containers - 1999 and 2001, pp 30-34. Forest Service, Southern Research Station, Asheville, USA.

Steinfeld, D., M.P. Amaranthus \& E. Cazares. 2003. Survival of ponderosa pine (Pinus ponderosa Dougl. ex Laws.) Seedlings outplanted with Rhizopogon mycorrhizae inoculated with spores at the nursery. Journal of Arboriculture 29: 197-207.

Theodorou, C. 1971. Introduction of mycorrhizal fungi into soil by spore inoculation of seed. Australian Forestry 35: 17-22.

Theodorou, C. \& G.D. Bowen. 1970. Mycorrhizal responses of radiata pine in experiments with different fungi. Australian Forestry 34: 183-191.

Vallejo, V.R., J. Aronson, J.G. Pausas \& J. Cortina. 2005. Restoration of Mediterranean woodlands. In: J.V. Andel \& J.J. Aronson (eds.), Restoration ecology: the new frontier, pp. 193-207. Blackwell Publishing, Oxford, UK.

Villar, P., J.L. Peñuelas \& I. Carrasco. 2000. Influencia del endurecimiento por estrés hídrico y la fertilización en algunos parámetros funcionales relacionados con la calidad de la planta de Pinus pinea. $1^{\text {er }}$ Simposio sobre el pino piñonero, Valladolid, Spain. 1: 211-218.

ZAR, J.H. 1999. Biostatistical analysis fourth ed. Prentice-Hall, Upper Saddle River, New Jersey. USA. 662 pp.

Recibido: 23.04 .12

Aceptado: 17.10 .12 